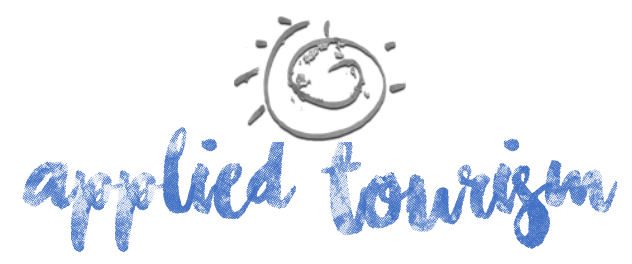

Volume 2, número 2, 2017, p. 180-197

\title{
TURISMO CEMITERIAL: proposta de roteirização a partìr das potencialidades turísticas impressas no cemitếrio civil de Santa Vitória do Palmar, RS, Brasil
}

\author{
Cláudia Brandão Schwab \\ Bacharel em Turismo Binacional \\ Universidade Federal do Rio Grande - FURG \\ animam1di@hotmail.com \\ Lucimari Acosta Pereira \\ Mestranda em Turismo e Hotelaria \\ Universidade do Vale do Itajaí \\ lucimari.svp@gmail.com
}

Recebido: 28 de junho, 2017

Aprovado: 01 de agosto, 2017

\section{RESUMO}

Este trabalho apresenta projeto elaborado durante estágio curricular obrigatório, no qual se analisaram as possibilidades de transformação do Cemitério Civil de Santa Vitória do Palmar em um atrativo turístico, a partir da realização de trilhas interpretativas em um processo de roteirização, com vistas à preservação de seu patrimônio. A metodologia utilizada foi análise SWOT partindo da inventariação turística. As incursões exploratórias foram desenvolvidas por meio de pesquisa bibliográfica e em periódicos. A pesquisa de campo realizada fez levantamento da infraestrutura, acessibilidade, segurança do espaço e elementos tumulares visando à elaboração do plano final de roteirização.

Palavras-chaves: Turismo Cemiterial. Trilhas interpretativas.Roteirização 


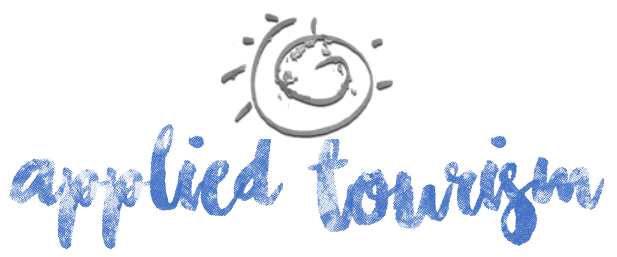

Volume 2, número 2, 2017, p. 180-197

\section{INTRODUÇÃO}

O presente artigo visa apresentar o projeto elaborado durante estágio curricular para a obtenção de título em Bacharel em Turismo Binacional pela Universidade Federal do Rio Grande - FURG, no ano de 2014 . Dispunha-se a apresentar o Cemitério Civil de Santa Vitória do Palmar, RS, Brasil, como um potencial atrativo turístico, indicando ações que possibilitassem a estruturação e implementação de trilhas interpretativas a partir da roteirização do local e, num segundo momento, a criação de um Memorial do Cemitério e das Pompas Fúnebres na cidade.

O projeto propunha ações de intervenção física no espaço, salvaguarda e proteção de bens materiais e documentos, divulgação e criação do roteiro de visitação, todas ações possíveis de implementação através de parcerias público-privadas e com apoio das Universidades atuantes na região. Além disso, previu a possibilidade de realização de roteiros regionais a partir da Revolução Federalista e da figura de Gumercindo Saraiva ${ }^{11}$, cujos restos mortais ali estão enterrados.

Quanto aos aspectos metodológicos do artigo, foi utilizado o método de inventariação Turística em conjunto com analise SWOT, de onde extraíram-se os dados que embasaram o diagnóstico. Este foi realizado entre os anos de 2013/2014 a partir de entrevistas com servidores públicos municipais vinculados ao Cemitério e com visitantes que participaram do roteiro experimental.

\section{OBJETO DE ESTUDO}

O Cemitério Civil de Santa Vitória do Palmar foi fundado em janeiro de 1889, alguns meses antes da proclamação da República. O terreno onde foi instalado foi adquirido, especialmente para este fim, em 1884. Tratava-se de um quadrado de 118,80 metros de

I Caudilho gaúcho, Líder da Revolução Federalista de 1893. Disponível em $<$ http://seer.upf.br/index.php/ph/article/view/3650/2397> Acesso em 20/01/2017

Schwab, C. B. \& Pereira, L. A. (2017). Turismo Cemiterial: proposta de roteirização a partir das potencialidades turísticas impressas no cemitério civil de Santa Vitória do Palmar, RS, Brasil. Applied Tourism, 2(2), 180-197. 


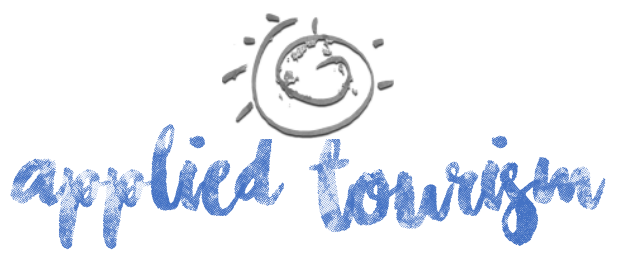

Volume 2, número 2, 2017, p. 180-197

lado, pertencente anteriormente ao Capitão Bernardo Rodrigues Correa e a sua esposa, Higina Dorothéa Souza. A escritura original está arquivada no Departamento de Ações Administrativas da Prefeitura Municipal, onde tivemos acesso a ela, bem como às demais escrituras relacionadas às ampliações posteriores.

Até 1888, os enterramentos eram feitos em um cemitério localizado na zona central da cidade, onde hoje se encontra o Colégio Estadual Santa Vitória do Palmar (Amaral, 2010, p. 26). A cidade cresceu em direção ao Cemitério e este crescimento provocou sua transferência de lugar. Ferreira (2009, p. 78) assim descreve a construção da cidade:

A cidade foi traçada com 14 ruas paralelas no sentido norte/sul e 8 perpendiculares a essas, no sentido leste/oeste. As ruas tinham a largura de $18 \mathrm{~m}$ e o comprimento das quadras era de aproximadamente $960.000 \mathrm{~m}^{2}$. Foi construída em torno de uma praça $^{\text {II }}$ e de uma igreja, e nesse entorno observa-se as construções mais importantes, herança da classe social que edificou e moldou a cidade.

Entre 1875 e 1900 a cidade passou de 201 a 502 imóveis urbanos, em uma onda de crescimento impulsionada pela implantação de novas formas de produção, de consumo e de distribuição. Uma classe de comerciantes começou a somar-se à dos ruralistas, que aplicavam seus excedentes em construção de prédios suntuosos na cidade, marcando na arquitetura o poder da elite rural. Esta marca de distinção social também era deixada dentro dos muros do Cemitério. Em 1910, eram já 596 os prédios urbanos e a população em 1920 passava das 11.000 almas, sendo que 4000 viviam na zona urbana (Ferreira, 2009, p. 82-83).

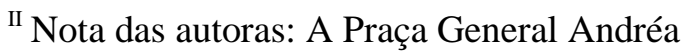




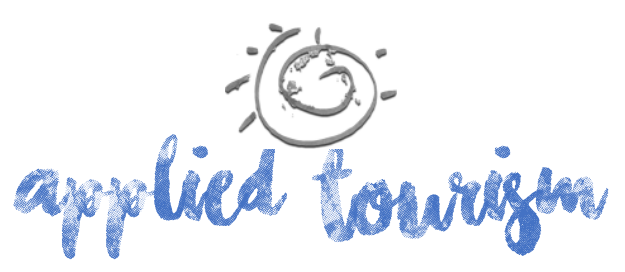

Volume 2, número 2, 2017, p. 180-197

Figura1 - Vista aérea da cidade com indicação dos dois cemitérios e da Praça General Andréa.

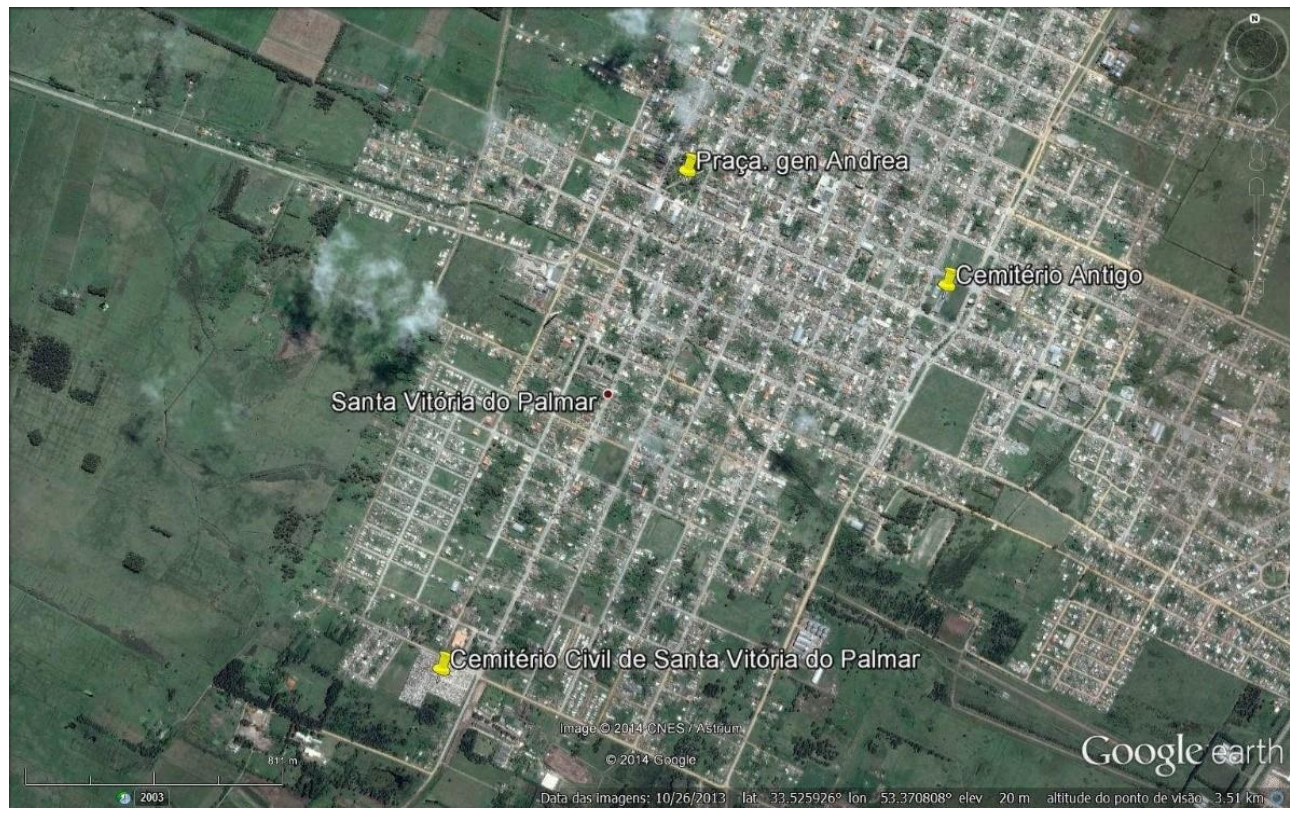

Fonte: Google Earth, 2014

Os funerais eram verdadeiros eventos sociais, a morte e seus rituais faziam parte dia-a-dia das cidades, mas o surgimento das ideias higienistas vindas da Europa e que apontavam os corpos mortos como responsáveis pela transmissão de diversas doenças, começou a tirar este caráter de festa dos rituais da morte, interditando-os ao convívio muito próximo dos vivos: os enterramentos dentro das igrejas foram proibidos e a recomendação era de se instalar cemitérios em locais afastados dos centros urbanos (Pagotto, 2004, p. 19).

Este processo se iniciou no Brasil ainda em 1789, por ato de Dona Maria de Portugal, tornou-se imperativo a partir de 1828, por intervenção do Imperador Dom Pedro I e passou a ser obrigatório, finalmente, com a publicação do Decreto Federal no 789, já na Primeira República (Borges, 2002). A transferência do local de enterramentos para o ponto mais alto da cidade, a Coxilha do Lítigio, provavelmente veio satisfazer estas necessidades. Os restos mortais enterrados no cemitério velho foram transferidos para o novo, cujo portão principal e muro, ainda existentes, foram construídos por João Batista Almeida, que foi também o primeiro zelador do lugar (Amaral, 2010, p. 27-28). 


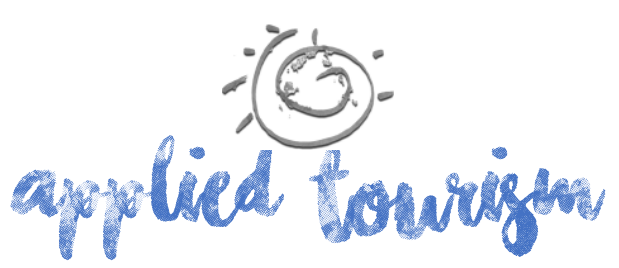

Volume 2, número 2, 2017, p. 180-197

O Cemitério Civil é administrado pela Prefeitura Municipal de Santa Vitória do Palmar, mais especificamente, pela Secretaria Municipal de Obras e Serviços Urbanos. Segundo o Prefeito, em entrevista concedida em 25 de agosto de 2014, o Poder Público preocupa-se com o Cemitério na medida das solicitações da comunidade, que normalmente só se manifesta a este respeito nas vésperas do Dia de Finados - 02 de novembro, ou de festas como o Dia dos Pais ou das Mães.

As diversas entrevistas realizadas com servidores públicos municipais e representantes do Poder Público forneceram detalhes sobre a administração do cemitério e acerca da superestrutura relacionada ao mesmo, que serviram de base para a compreensão do funcionamento do espaço e para a elaboração do projeto de estágio.

O Cemitério é cercado pelos lados sul e leste por um muro branco, de tijolos, construído no ano de 1888, da mesma forma que o portão em ferro fundido. Por sobre o muro vêemse, desde o lado de fora, algumas de suas esculturas tumulares e muitas cruzes. A calçada não tem calçamento de pedras ou cimento, à exceção do trecho em frente ao portão principal. Do lado interno, ao longo dos muros originais, há catacumbas construídas na mesma época (algumas delas foram derrubadas, mas a maior parte ainda é utilizada). À direita do portão principal está uma pequena sala que serve de escritório da administração e almoxarifado. Nesta sala são guardados equipamentos como pás, enxadas, cimento, uniformes de trabalho e documentos. O mobiliário é restrito a uma mesa e uma cadeira velhas e em más condições de conservação.

Há muitos mausoléus que, ao longo dos anos, foram sendo reformados e tiveram suas características originais alteradas, com uma presença muito grande do uso de azulejos e lajotas. Percebem-se também muitos jazigos abandonados, cobertos de musgo e limo, incluindo lápides em mármore ilegíveis pela presença destes elementos. A riqueza em lápides entalhadas em mármore e em fotos tumulares é bastante para instigar estudos específicos. 


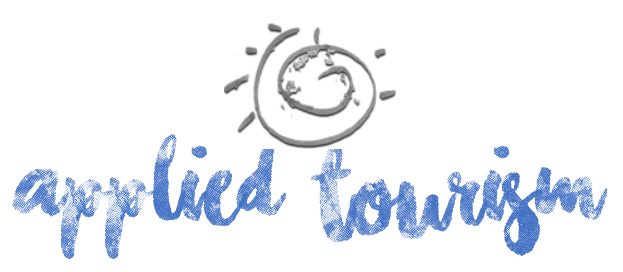

Volume 2, número 2, 2017, p. 180-197

Figura 3 - Vista de satélite do Cemitério Civil de Santa Vitória do Palmar

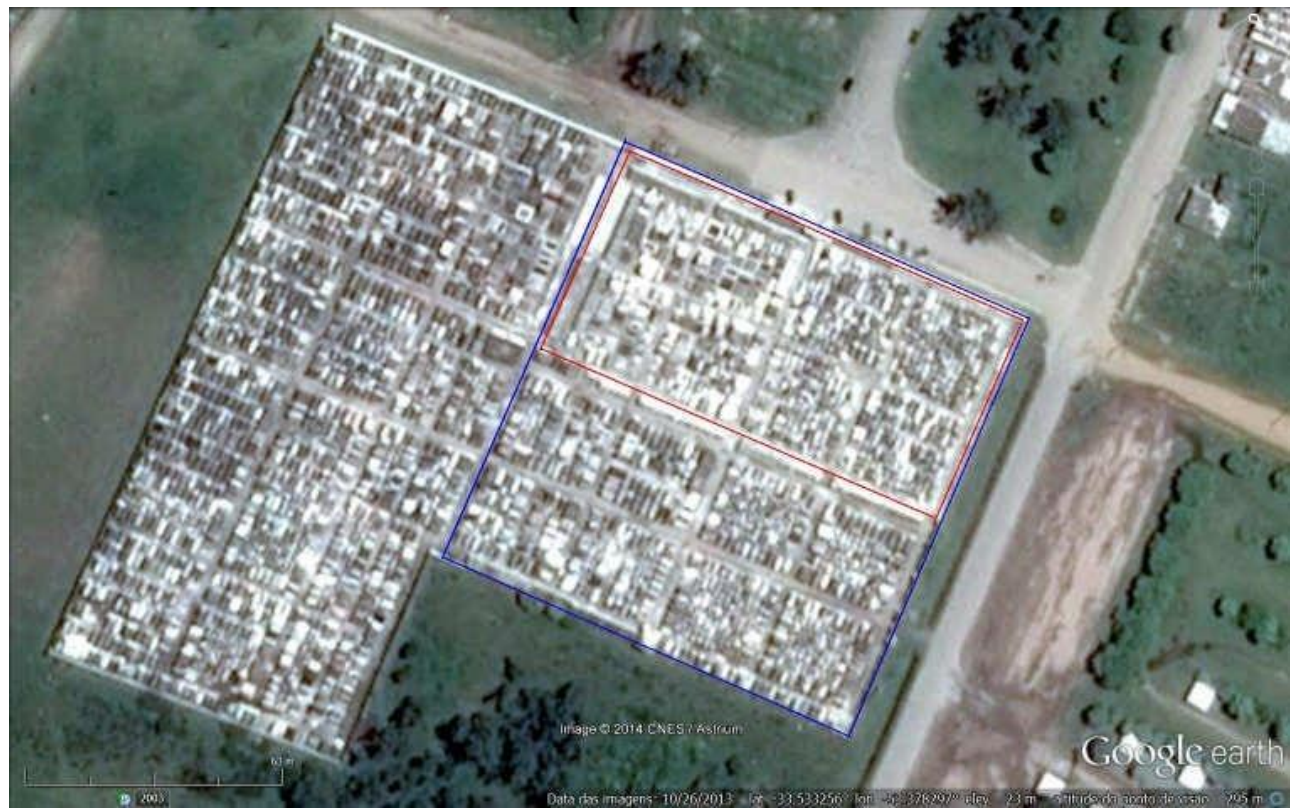

Fonte: Google Earth, 2014

A área abordada por este estudo mede aproximadamente 102,0 m de frente por 55,0 m de lado $\left(5610 \mathrm{~m}^{2}\right)$. A Figura 3 mostra uma visão geral do Cemitério Civil de Santa Vitória do Palmar, extraída do Google Earth. Nela marcamos um quadrado mais à direita, com uma linha azul, indicando a área original. Pode-se perceber que esta está dividida em quatro quadrantes, subdivididos cada qual, por sua vez, em mais quatro quadras. Este estudo limita-se apenas à zona onde se encontram os jazigos mais antigos, aqueles transladados do cemitério desativado e os construídos até as primeiras décadas do século XX (os dois quadrantes sinalizados em vermelho na Figura 3).

Como já dito antes, a época em que ocorreu a inauguração do novo Cemitério coincidiu com um período de crescimento urbano, associado a um desenvolvimento econômico importante. A elite rural investia na construção de prédios suntuosos na zona central da cidade e da mesma forma, atendendo aos ditames sociais do período, construía jazigos que perpetuassem na memória da comunidade a riqueza e o status de suas famílias. Estes jazigos estão situados justamente na área abrangida pelo estudo. No século XIX, a maioria eram em alvenaria, com lápides requintadas entalhadas no mármore. Nas primeiras 


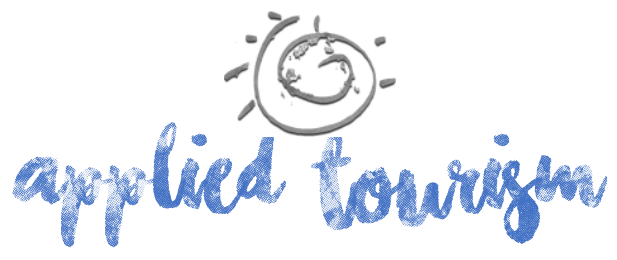

Volume 2, número 2, 2017, p. 180-197

\section{REFERENCIAL TEÓRICO}

\section{Cemitério e Turismo Cemiterial}

Cemitérios são monumentos, por si sós. Segundo Camargo (2002, p. 24), em relação a monumentos, "[...] A raiz da palavra latina nos remete a momento ou lembrança. [...] os monumentos, na acepção comum do termo, são edificações ou construções que pretendem perpetuar a memória de um fato, de uma pessoa, de um povo". Cemitérios são lugares de memória, onde repousam os restos de nossos entes queridos, repletos de elementos que perpetuam a memória destes entes.

Halbwachs (apud Burke, 2000, p. 19) afirma que "as memórias são construídas por grupos sociais. São os indivíduos que lembram - no sentido literal, físico - mas são os grupos sociais que determinam o que é 'memorável' e também como será lembrado". Este "como será lembrado" está presente dentro do espaço cemiterial: as formas de enterramento, os rituais de adeus e de saudade, com as mudanças características de cada época estão ali, registradas em cada uma das tumbas.

Patrícia Neuhaus, em sua dissertação de Mestrado em Arquitetura pela Universidade Federal do Rio Grande do SUL - UFRGS (2012, p. 26) fala sobre as relações entre sujeito (visitante), o espaço cemiterial e a morte. Apontando os cemitérios como espaços de memória, além de espaços destinados aos cultos e rituais de sepultamento, a autora detecta que estes locais têm como função colocar a morte e os mortos em uma "pseudoexistência mnemônica", que se revela tanto externamente, nos monumentos mortuários, como internamente, nas lembranças que cada um guarda de seus mortos. Desta forma, afirma a autora que a experiência cemiterial comporta dois níveis de relação: a do sujeito com o espaço e a do sujeito com o morto.

Ou seja: para que a visitação se dê (e nela, a experiência do espaço), é necessário que haja uma experiência prévia, a da memória do morto (aí a relação sujeito-morto), além da 


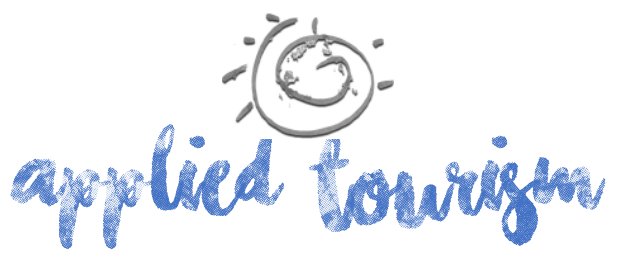

Volume 2, número 2, 2017, p. 180-197

intenção da visita. Como neste trabalho propomos a visitação ao Cemitério com o fim turístico, devemos considerar que nem sempre o visitante terá a memória do morto (pois que eventualmente não terá ninguém querido enterrado ali), assim sendo, para possibilitar a efetivação da vivência, adquire importância a interpretação patrimonial do espaço, que deverá despertar e/ou criar memórias nos visitantes, tendo em vista a intenção da visita, neste caso, turística.

O Turismo Cemiterial surgiu como tendência em meados dos anos 80 nos Estados Unidos e Europa, tornando-se um segmento da atividade turística posteriormente. A visitação pode ser precedida por curiosidade mórbida, visitação a túmulos de pessoas famosas ou interesse pela arte tumular, que vem agregada de cultura patrimonial (Borges, 2002; Gastal \& Moech, 2007).

Nesse sentido, a partir do inventário do patrimônio escultórico, registro da história e elementos vinculados à cultura e à memória do município e da região, é considerado possível o uso do Cemitério Civil como atrativo. Como parte essencial desse processo foram considerados os seguintes aspectos: relação do visitante com o Cemitério, o que pensa sobre o uso turístico do mesmo e quais suas impressões após a visitação (Puerto \& Baptista, 2015; Gastal \& Moech, 2007).

No contexto da pesquisa consideraram-se visitantes os residentes, tendo em vista o Cemitério não ser um atrativo turístico consolidado e levando em conta que é necessário reconhecimento pela comunidade do valor do espaço antes de estimular o turismo. O confronto com o novo e o inesperado provoca uma "mobilização subjetiva que levaria a re-olhar, a repensar, a reavaliar, a ressignificar não só a situação, o ambiente, as práticas vivenciadas naquele momento e naquele lugar, mas muito de suas experiências passadas" (Gastal \& Moesch, 2007).

À parte do conceito de turista, que leva em consideração a necessidade de deslocamento espacial para local diferente daquele onde se reside, o cidadão que visita outro bairro ou 


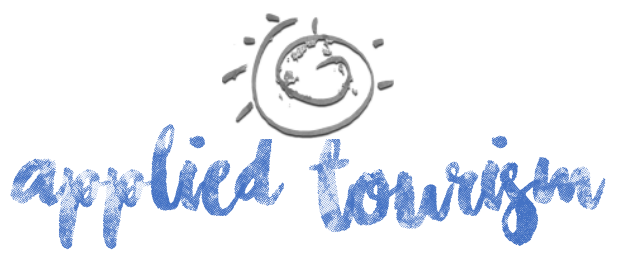

Volume 2, número 2, 2017, p. 180-197

espaço dentro de sua cidade, em situação diversa à de sua rotina normal, também vivencia estes estranhamentos e desperta estas subjetividades (Gastal \& Moesch, 2007).

O turismo tem sido apontado como alternativa para alavancar a economia do município de Santa Vitória Do Palmar no discurso dos representantes do Poder Público Municipal, no entanto ainda não interfere na economia local (Azambuja, 1992). Algumas iniciativas têm sido adotadas para este desenvolvimento, inclusive a instalação do Campus da FURG no Município, com o curso de Turismo Binacional.

O debate sobre turismo e o uso dos espaços na cidade vem de longa data, juntamente a outros como a insuficiência da infraestrutura e a atratividade da região. Nesse sentido se insere a importância do planejamento turístico, através do qual dá-se o processo de crescimento social e econômico de uma localidade (Azambuja, 1992; Beni, 2011).

O cemitério enquanto "produto turístico" vem complementar algumas ações já implementadas pela Secretaria Municipal de Cultura, Esporte e Turismo, como os roteiros do Centro Histórico e das Fazendas Históricas, oferecidos em situações específicas (por exemplo, na Semana Nacional dos Museus). As propostas de roteiros regionais apresentadas no projeto vão ao encontro do que prevê o MTUR em seu Plano de Regionalização do Turismo e estão em conformidade com o disposto no plano de Desenvolvimento do Turismo do Rio Grande do Sul para 2012 - 2015 (Brasil, 2013).

Outro aspecto importante é que o extremo sul do RS é rota de trânsito de turistas do Mercosul Nesse contexto os projetos turísticos devem levar em conta este fato: o turista não tem de ser trazido até a região, tem de ser apenas atraído, mobilizado a permanecer na região. 


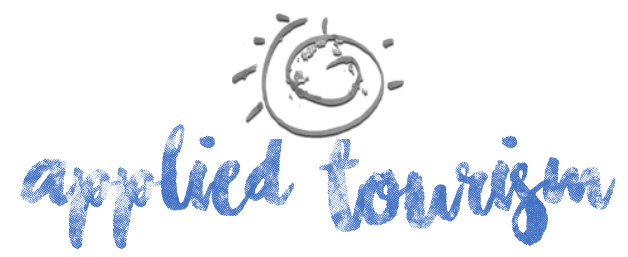

Volume 2, número 2, 2017, p. 180-197

\section{METODOLOGIA}

Os estudos para a proposta foram feitos entre os anos de 2013/2014, através de pesquisas de campo nas quais foram registradas as características do local (infraestrutura, acessibilidade, segurança) e coletados dados para o inventário: fotos dos jazigos, identificando suas características, dados descritivos, curiosidades e histórico do enterramento, além do mapeamento da área. O inventário seguiu o modelo proposto por Bastianello (2010, p. 127) e os elementos característicos descritos segundo Bellomo (2008).

A partir do inventário foi elaborado o roteiro de visitação, dando destaque à arte tumular, sua beleza e simbologia; o belo em suas diferentes formas - o grandioso e o singelo; os elementos de cultura popular e religiosa; a história municipal e regional; os traços de formação cultural e étnica da sociedade local; as diferentes formas de expressão da saudade e os riscos a que se encontra exposto o patrimônio existente no Cemitério.

Compunham o roteiro: mapa de visitação e texto-guia indicando as paradas, os elementos destacados do conjunto, sua descrição e vínculo com os objetivos da mostra, buscando despertar o interesse e curiosidade do visitante, sem ser didático nem repetitivo (uma interpretação do espaço, incluindo desde dados históricos até elementos da simbologia da arte tumular, curiosidades, lendas e histórias populares), com cerca de uma hora de duração.

A trilha interpretativa foi a ferramenta usada para compreender a relação da comunidade com o espaço cemiterial, associada à realização de entrevistas com os visitantes através de grupos focais, logo após as visitas.

Pesquisa documental e entrevistas semi-estruturadas com funcionários e membros do poder público forneceram as informações sobre a superestrutura: legislação, procedimentos, zeladoria e administração. A pesquisa bibliográfica forneceu o 


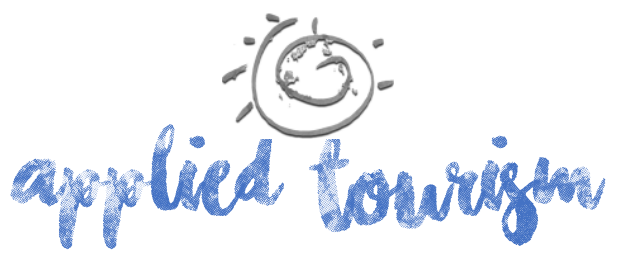

Volume 2, número 2, 2017, p. 180-197

embasamento para analisar os dados e compreender os processos vinculados ao tipo de turismo proposto. O projeto foi elaborado a partir de uma análise SWOT dos dados coletados.

\section{RESULTADOS}

\section{Diagnóstico}

Os primeiros registros de ocupação deste território datam do início do século XVIII. Em março de 1778 foi colocado o $1^{\circ}$ marco de fronteira na foz do Arroio Chuí. Em 19 de dezembro de 1855 foi criada a povoação de Andréa - cuja padroeira era Santa Vitória elevada à categoria de Vila em 30 de outubro de 1872 e a de Cidade em 24 de dezembro de 1888 (Ibge, p.1, 2015; Amaral, 2010).

O Cemitério, fundado em janeiro de 1889, teve seu terreno adquirido em 1884 especialmente para esse fim. Até 1888, estava localizado na zona central da cidade. Os restos mortais ali enterrados foram transferidos para o novo Cemitério, cuja portada principal e muro, ainda existentes, foram construídos neste mesmo ano por João Batista Almeida, primeiro zelador. O portão em ferro fundido também é de 1888 (Amaral, 2010).

Em meados do século XX houve a primeira ampliação, em terreno contíguo ao original e adquirido pela prefeitura em 1934. Atualmente, mede aproximadamente $24.640 \mathrm{~m}^{2}$. O quadrado original adquirido pela Prefeitura em 1884 media $13.924 \mathrm{~m}^{2}$. Este projeto abrange apenas os dois quadrantes mais antigos (metade da área original), onde estão os jazigos transladados do cemitério desativado e os construídos até as primeiras décadas do século XX.

Não há calçada de pedras ou cimento, à exceção do trecho em frente ao portão principal. Do lado interno, ao longo dos muros originais, há catacumbas construídas na mesma época. À direita do portão principal está uma pequena sala, escritório da administração e almoxarifado, onde são guardados equipamentos de trabalho e documentos. 


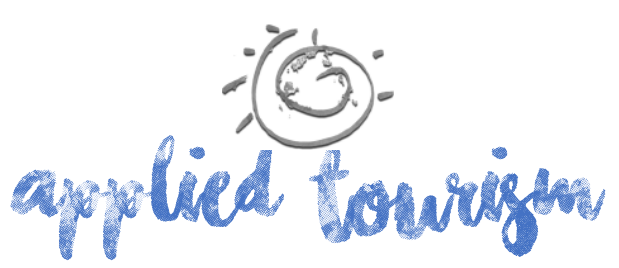

Volume 2, número 2, 2017, p. 180-197

É frequente a reforma de mausoléus, alterando suas características originais. Percebem-se também vários jazigos abandonados, cobertos de musgo e limo, incluindo lápides ilegíveis.

A riqueza em lápides entalhadas em mármore e em fotos tumulares é um dos destaques do conjunto. No século XIX, a maioria eram jazigos em alvenaria, com lápides requintadas entalhadas no mármore. Nas primeiras décadas do século XX surgiram mausoléus em mármore, com uma estatuária composta por anjos, crianças, a Sagrada Família e outros elementos de representação cívica ou religiosa.

Neste Cemitério repousam os restos mortais de Gumercindo Saraiva, um dos últimos caudilhos e figura de destaque no contexto político do final do século XIX, líder da Revolução Federalista, que desperta interesse de visitantes de toda a região do cone-Sul, segundo depoimento do zelador.

Quadro1- Pontos Fortes

\begin{tabular}{|c|}
\hline Pontos fortes \\
\hline Riqueza em referências históricas, sociais e culturais \\
\hline Poder público acessível ao diálogo \\
\hline $\begin{array}{l}\text { Possível trabalhar conscientização e reconhecimento da importância do espaço sem } \\
\text { muito custo, a partir da trilha interpretativa, facilitada pela presença de Universidades } \\
\text { na região que podem atuar em parceria com o poder público }\end{array}$ \\
\hline $\begin{array}{l}\text { Possível trabalhar conscientização e reconhecimento da importância do espaço sem } \\
\text { muito custo, a partir da trilha interpretativa, facilitada pela presença de Universidades } \\
\text { na região que podem atuar em parceria com o poder público }\end{array}$ \\
\hline Dedicação e zelo dos servidores e funcionários \\
\hline $\begin{array}{c}\text { Boa aceitação dos visitantes à proposta, acusando um novo olhar sobre o cemitério } \\
\text { como espaço de reflexão sobre a cultura, história e sociedade, bem como sobre vida e } \\
\text { morte }\end{array}$ \\
\hline
\end{tabular}

Fonte: Elaborado pelas autoras 


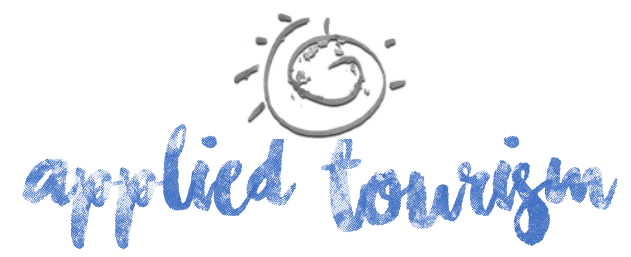

Volume 2, número 2, 2017, p. 180-197

Quadro 2- Pontos Fracos

\begin{tabular}{|c|}
\hline Pontos fracos \\
\hline Insegurança, havendo registro de vandalismo e roubo \\
\hline Instalações administrativas inadequadas \\
\hline Não há mapa, numeração de quadras ou jazigos nem regulamento de uso do espaço. \\
\hline Ausência de estrutura para apoio aos visitantes e acessibilidade \\
\hline A ação administrativa se dá na medida dos apelos da comunidade, sem atuação \\
preventiva \\
\hline Jazigos sem o devido cuidado ou abandonados \\
\hline Elementos datados da inauguração, como o muro e o portão da entrada, em más \\
condições de conservação
\end{tabular}

Fonte: Elaborado pelas autoras

\section{Prognóstico}

A implantação de um roteiro de visitação no Cemitério Civil, oferecida em um primeiro momento aos residentes, poderá despertar na comunidade um olhar diferenciado sobre este patrimônio, levando à conscientização sobre seu valor e importância de sua proteção, facilitando a implantação de ações protetivas, como o tombamento da área.

A oferta de passeios turísticos para residentes é importante para a implantação de outras ações de desenvolvimento turístico na região, pois transforma o morador local também em turista e aproxima a comunidade deste processo. O "pensar" o turismo passa a ser parte da realidade diária do cidadão, impulsionando sua participação.

O Cemitério Civil guarda os restos mortais dos cidadãos que aqui viveram desde o período inicial de formação da cidade (meados do século XIX). Cada jazigo traz impresso em suas lápides um pouco da memória social, cultural, étnica desta sociedade. O conjunto é representativo dos ciclos econômicos, da estratificação social, dos hábitos, rituais e crenças deste grupo social e apresenta rica arte tumular nas grandes esculturas e imagens e nos entalhes das lápides. 


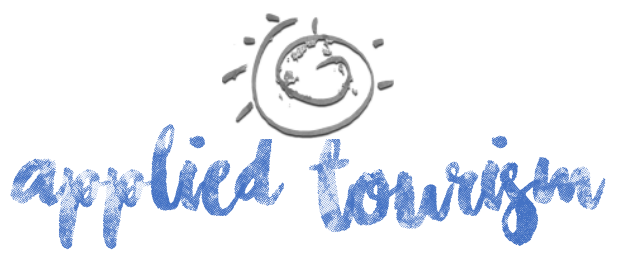

Volume 2, número 2, 2017, p. 180-197

A presença de Gumersindo Saraiva foi destacada pelos visitantes e entrevistados e seu jazigo é procurado regularmente por visitantes de outras localidades. Queda, então, evidente a possibilidade de trabalhar roteiros a partir de sua história, incluindo o país vizinho, Uruguai, onde a família Saraiva teve papel relevante, como outras localidades do RS que foram palco de eventos na Revolução Federalista. O local de seu primeiro sepultamento, no Cemitério dos Capuchinhos de Santo Antônio, em Itacurubi, Região Missioneira, guarda um monumento em sua homenagem.

Na cidade de Santa Vitória do Palmar há ainda as residências e as fazendas e campos que pertenceram à família que poderiam compor um roteiro local, para o qual certamente haveria uma importante demanda.

\section{CONSIDERAÇÕES FINAIS}

Estes estudos tornam-se relevantes não apenas pelas possibilidades de valorização e reconhecimento de um patrimônio artístico e cultural do Município e sua consequente preservação: o Cemitério Civil é local de livre acesso à comunidade, independentemente de situação econômica, social ou religiosa. Guarda dentro de seus muros relevante conjunto artístico que pode vir a tornar-se um museu a céu aberto, para a visitação de turistas e de residentes.

Durante o estudo observou-se pouco material publicado sobre o assunto. Acerca do objeto deste trabalho há apenas uma monografia de conclusão de pós-graduação lato sensu em Memória Social pela FURG, de 2010, que trata das Pompas Fúnebres no Município e apresenta alguns dados e informações relevantes sobre o Cemitério.

"A conservação da memória dos mortos é um dos fatores de identidade e coesão das famílias, tribos e das comunidades" (Bellomo, 2008, p. 13). Para o autor, cemitérios são reproduções dos espaços sociais dos vivos, neles estão projetados valores, crenças, estruturas socioeconômicas e ideologias das comunidades a que pertencem. Dentro dessa 


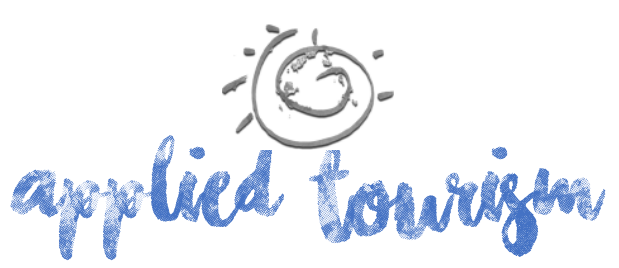

Volume 2, número 2, 2017, p. 180-197

ótica, o turismo cemiterial é uma ferramenta de construção da cidadania e a preservação do patrimônio. Criar roteiros e espaços turísticos voltados à comunidade local é o primeiro passo para consolidar um desenvolvimento turístico saudável.

Sugere-se novos estudos para que hajam contribuições gerenciais e também acadêmicas tendo em vista o número escasso de publicações sobre a referida temática.

\section{REFERÊNCIAS}

Amaral, M. E. (2010). Cemintério e Pompas Fúnebres: Foco de Interpretação Cultural e Social da Comunida Santa - Vitoriese. . Rio Grande, RS, Brasil : Universidade Federal do Rio Grande - FURG.

Azambuja, P. (1992). Santa Vitporia do Palmae: Um Município do Prata . Santa Vitória do Palmar: Grafica Jerivaçu.

Bastianello, E. M. (2010). Os monumentos funerarios do Ceminterio da casa de caridade de Bagé e seus significados culturais: Memória publica, étnica e artefactual1958-1950. Pelotas : UFPEL.

Bellomo, H. R. (2008). Cemintérios Do Rio Grande do Sul : Arte, Sociedade, Ideologia. Porto Alegre: Edipuc.

Beni, M. C. (2011). Globalização do Turismo: Megatendências do Setor e Realidade Brasileira . São Paulo : Aleph.

Borges, M. E. (2002). ANPAP na Travessia das Artes, 2001 de 2001. Imagens devocionais nos cemitérios do Brasil. (ANPAP, Ed.) XI Encontro da associação Nacional de Pesquisa em artes plásticas, 2002- ANPAP, 1, 10-15.

Brasil, M. T. (2013). Programa de Regionalização do Turismo: diretrizes. Brasilia - DF.

Burke, P. (2000). História como memória social . Rio de Janeiro: Civilização Brasileira.

Camargo, H. L. (2002). Patrimônio Histórico e Cultural. São Paulo- SP: Aleph .

Ferreira, L. R. (2009). Transformação na paisagem urbana de Santa Vitória do Palmar- RS a produção da cidade. Porto Alegre : Universidade Federal do Rio Grande do Sul - URGS .

Gastal, S., \& Moech, M. M. (2007). Turismo Politicas Públicas e Cidadania. São Paulo - SP: Aleph.

IBGE. (26 de Julho de 2015) Bilbioteca. Santa Vitória do Palmar, Rio Grande do Sul. Histórico. retreived from bttp://biblioteca.ibge.gov.br/visualizacao/dtbs/riograndedosul/santavitoriadopalmar.p $d f$. 


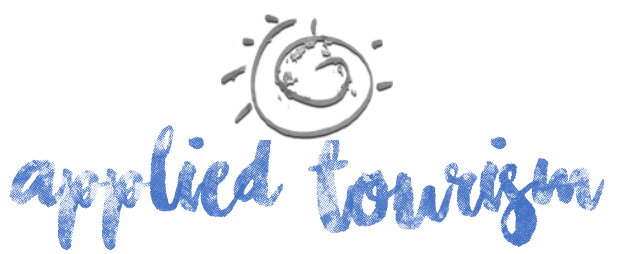

Volume 2, número 2, 2017, p. 180-197

Neuhaus, P. G. (2012). A experiência do espaço na visita ao cemitério contemporâneo. Porto Alegre: Dissertação de Mestrado Programa de Pós- Graduação em Arquitetura da universidade Federal do Rio Grande do Sul.

Pagoto, A. A. (2004). Do âmbito sagrado da igreja ao cemitério público - Transformações Funebres em São Paulo. São Paulo: Imesp.

Puerto, C. B., \& Baptist, M. L. (2015). Espaço cemiterial e Turismo: campo de ambivalência da vida e morte. Revista Iberoamericana de Turismo - RITUR, 42-53. 